\title{
EFFECTIVENESS OF CHLORHEXIDINE BATH, SALINE BATH, AND STANDARD BATH ON BACTERIAL COLONIZATION ON THE SKIN
}

\author{
DIVYA ABRAHAM ${ }^{1 *}$, VINITHA RAVINDRAN ${ }^{2}$, VINSLEY ROSE ${ }^{3}$, JOY SAROJINI MICHAEL ${ }^{4}$ \\ ${ }^{1}$ Department of Amrita College of Nursing, Amrita Vishwa Vidyapeetham, Kochi, Kerala, India. ${ }^{2}$ Department of College of Nursing, \\ Christian Medical College, Vellore, Tamil Nadu, India. ${ }^{3}$ Department of Child Health, Christian Medical College, Vellore, Tamil Nadu, India. \\ ${ }^{4}$ Department of Microbiology, Christian Medical College, Vellore, Tamil Nadu, India.Email: divyamercyabraham24@gmail.com
}

Received: 13 March 2018, Revised and Accepted: 21 June 2018

ABSTRACT

Objective: The main objective of the study was to determine whether bathing with $2 \%$ chlorhexidine or $0.9 \%$ saline or standard soap and water will reduce the bacterial colony count on skin effectively.

Methods: Quantitative approach with experimental design and consecutive sampling was used. The study was conducted among 102 children admitted in pediatric wards of Christian Medical College, Vellore. Swabs from axilla and groin were collected at $0 \mathrm{~h}, 2 \mathrm{~h}$, and $24 \mathrm{~h}$ of intervention to determine the bacterial colony count in subjects.

Results: The results showed that, of 102 children, 73 (71.56\%) of them had high axillary colony count and 69 (67.64\%) of them had high groin colony count during admission. Majority $88.2 \%$ and $78 \%$ of them had colonization with coagulase-negative staphylococcus in the axilla and groin, respectively. There was no significant difference in the bacterial colony count in axilla at 2 and $24 \mathrm{~h}$ in all three groups. There was a significant difference in the bacterial colony count in groin at $2 \mathrm{~h}$ after the intervention in the chlorhexidine group, and the difference was not significant at $24 \mathrm{~h}$. The colony count was not significantly different at $2 \mathrm{~h}$ post-intervention in saline and standard soap and water group but was statistically different in these groups at $24 \mathrm{~h}$ after the intervention.

Conclusion: Chlorhexidine has shown to be effective for a shorter duration and it can be adopted for children who are undergoing invasive procedures and preoperatively in surgical wards while continuing routine standard bath for all children which is considered to be cost effective too.

Keywords: Chlorhexidine bath, Saline bath, Standard bath, Bacterial colonization.

(C) 2018 The Authors. Published by Innovare Academic Sciences Pvt Ltd. This is an open access article under the CC BY license (http://creativecommons. org/licenses/by/4. 0/) DOI: http://dx.doi.org/10.22159/ajpcr.2018.v11i10.25893

\section{INTRODUCTION}

Hospital-acquired infections are the greatest concern in the delivery of holistic health care at present. Most of the microorganisms are becoming resistant to the antibiotics we administer to the patients leading to prolonged hospital stay and increased morbidity and mortality. Infants and children are more prone to infections as compared to adults because of their increased susceptibility related to their age and developmental level.

Skin flora more accurately referred to as the skin microbiome or skin microbiota is the microorganisms which reside on the skin. Majority of the skin microbes are bacteria accounting for 1000 different species. The total number of bacteria on an average human has been estimated at $10^{12}$, most of which are found in the superficial layers of epidermis. Skin flora is usually non-pathogenic and is either commensals (not harmful to the host) or mutuality (offer a benefit). A few resident microbes, however, can lead to adverse outcomes due to infections when the number increases or when contextual conditions, both individual (break in skin barrier, poor health status, and illness) and environment (hospitalization), become favorable for their growth.

Staphylococcus aureus (SA) is the common bacteria, and 25-30\% people carry it in their skin or nose. It spreads from one person to another person by skin-to-skin contact. These bacteria thrive in warm moist places. Common sites of colonization include nostrils, umbilicus, axilla, and groin. These bacteria are capable of invading the skin and resulting in the major cause for nosocomial infection [1]. SA is one of the most important pathogens affecting humans, has acquired resistance to various antibiotics, and is a leading cause of hospital- and community-acquired infections, manifesting from minor skin diseases to life-threatening infections. Methicillin-resistant SA (MRSA) was first described in 1961, reported after 1 year of introduction of methicillin, and has emerged as one of the most important nosocomial pathogens, especially in the last two decades. MRSA is now endemic in India. The incidence of MRSA varies according to the region, $25 \%$ in the western part of India to $50 \%$ in South India [2]. The MRSA is a species of bacterium commonly found on the skin and/or in the noses of healthy people. Approximately one-third of healthy people carry this type of infectious bacteria. Although it is usually harmless at these sites, it may infrequently get into the body through breaks in the skin such as abrasions, cuts, wounds, surgical incisions, or indwelling catheters that may cause infections [3].

Hospitals in India have a high burden of infections in their intensive care units (ICU) and general wards, many of which are resistant to antibiotic treatment. The first national wide survey conducted disclosed that $87 \%(39 / 45)$ of hospitals participated of 3130 inpatients surveyed 972 nosocomial infections were identified among 597 patients, an overall prevalence of $19.1 \%$. The most frequent infections were related to the urinary tract (48.2\%), vascular catheter use $(34.7 \%)$, and surgical site $(24.7 \%)$. Resistance of leading nosocomial pathogens to antimicrobial therapy included methicillin resistance (52.5\%) among SA [4].

Skin is the body's first barrier against bacteria that cause infections. As discussed earlier, most of these bacteria harbor in the superficial layers of the skin (epidermis). However, under favorable conditions such as sickness and long hospitalization, these organisms can lead to adverse outcomes like infections [5]. 
Such life-threatening infections have been instrumental in bringing forth various infection control measures in the hospital. The Hospital Infection Control Committee (HICC) emphasizes on the use of personal protective measures and handwashing techniques. Regular classes are conducted by HICC on these measures. In the same instance, few other areas, which also play an important role in reducing infection such as skin care (bath), are taken for granted by health-care professionals. Even though chlorhexidine is proven to be an effective cleanser and has been used to reduce microorganisms on the skin, it can be expensive. Efficacy of alternative cost-effective regular cleansing agent superior to soap and water needs to be evaluated. What we practice in pediatric department is giving bath with soap and water, but a study has shown that it is not effective in reducing the bacterial colonies on the skin [6]. Moreover, these organisms present on the skin under favorable conditions can penetrate through the skin, resulting in bloodstream infections, catheter-associated infections, and other nosocomial infections. Hence, it is important to remove these organisms before resulting in adverse reactions. One of the effective methods in removing the organisms is by giving an effective bath.

A large community-based randomized control study was done in Southern Nepal using chlorhexidine wipes in low birth weight babies. Experimental group received the chlorhexidine wipes, and the control group received standard bath. The authors reported a decline in mortality, and they concluded that the use of chlorhexidine wipes significantly lowered the all-cause mortality among low birth weight infant [7].

A randomized clinical trial was carried out in the neonatal ICU of AIIMS using $0.25 \%$ chlorhexidine for skin cleansing. 60 newborns were included in the study with 20 in each group: One group received chlorhexidine bath, one received normal saline bath, and the third group was control. They assessed the skin temperature, colonization, and skin condition in all three groups. They found that there was no difference in mean temperature in all the groups. At $24 \mathrm{~h}$, skin colonization rates in the axilla were $22.2 \%, 52.7 \%$, and $57.9 \%$ in chlorhexidine, saline, and non-cleansing (soap and water), respectively. Skin cleansing with chlorhexidine reduced the incidence of colonization by $62 \%$ compared with non-cleansing, but there was no significant reduction when compared with saline cleansing. Hence, they concluded that single skin cleansing with $0.25 \%$ chlorhexidine did not aversively affect skin condition or temperature in hospitalized preterm infants and reduced axillary skin colonization at $24 \mathrm{~h}$ after the intervention [8].

This study was an attempt to determine the effectiveness of chlorhexidine, saline bath, and standard bath in reducing skin bacterial colonization and skin health status in children getting admitted to the pediatric wards and thus finding an effective yet cost-effective way of reducing the burden of hospital-acquired infections.

\section{METHODS}

The study was conducted among 102 children who got admitted to the pediatric wards of tertiary care hospital, Vellore. Subjects were selected using non-probability consecutive sampling. Written consent was obtained from the parents of the subjects after explaining the purpose of the study. After getting the consent, the researcher divided the subjects into three groups using a random table numbers. A pre swab was taken from the axilla and groin of all the subjects by a person who was blinded to the study. Interventions were delivered to the subjects by the investigator. The standard bath group (control group) received standard bath with soap and water by the assigned staff/student, chlorhexidine wipe bath using chlorhexidine wipes, and the saline wipe bath using $0.9 \%$ saline, and bath towel was given by the investigator. Post-skin swab was taken from the axilla and groin of the subjects at $2 \mathrm{~h}$ and at $24 \mathrm{~h}$ by the same individual who was blinded to the intervention. The collected swabs were delivered to microbiology laboratory within 30 min of collection by the researcher. The results were obtained from the laboratory after $24 \mathrm{~h}$. The results were obtained from laboratory and coded as 1 - no growth (no colony), 2 - scanty growth (colony count
$<20$ ), 3 - moderate growth (colony count 20-100), and 4 - high growth (colony count $>100$ ). Data analysis was performed using descriptive and inferential statistics.

\section{RESULT}

Section I: Description of sociodemographic variables of the subjects

The data presented in Table 1 summarize that majority (40.2\%) of children were in the age group of infant (0-1 years) and $61.8 \%$ were males. More than half $(69.6 \%)$ of children were from rural community and most (39.2\%) were from middle-class socioeconomic status.

Section II: Description of the microorganisms present in the axilla and groin of the subjects

The data depicted in Figs. 1 and 2 show that majority of the subjects $(88.2 \%)$ had high colony count on the axilla and $78 \%$ of had high colony count on the groin with coagulase-negative staphylococcus.

Section III: Description of the effectiveness of chlorhexidine bath, saline bath, and standard bath on bacterial colonization on the skin at $2 \mathrm{~h}$ and $24 \mathrm{~h}$ of intervention

The data described in Tables 2 and 3 show that there is no significant difference in the axillary colony count of the subjects at $2 \mathrm{~h}$ and $24 \mathrm{~h}$ of intervention. However, data presented in Table 4 show that there is a significant difference noticed in subjects received chlorhexidine

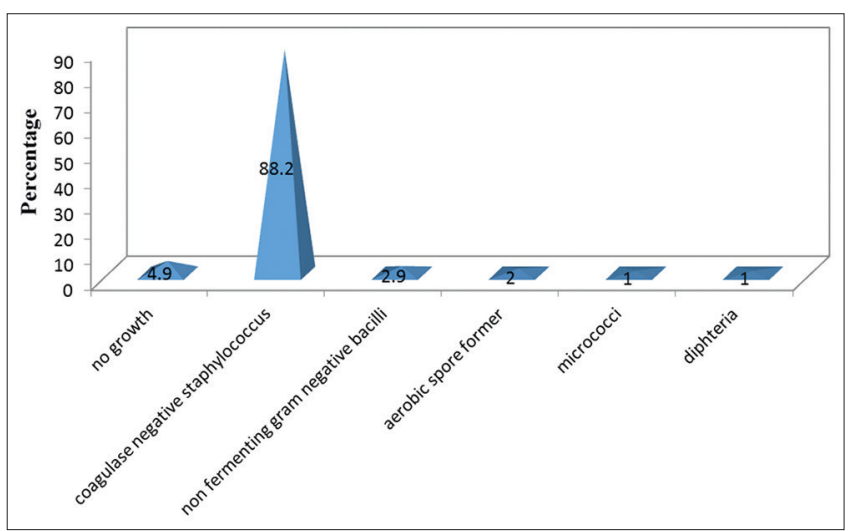

Fig. 1: Percentage distribution of children according to the microorganisms present in the axilla during the admission (within $24 \mathrm{~h}$ ) n=102

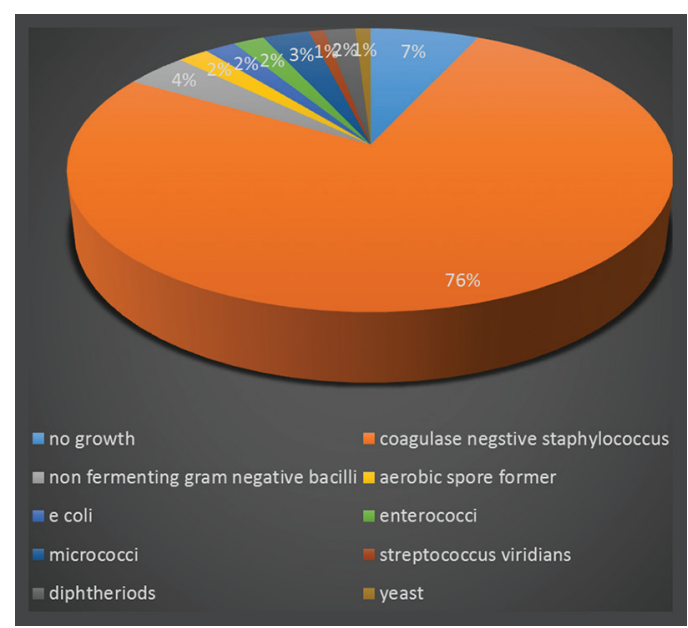

Fig. 2: Percentage distribution of children according to the microorganisms present in the groin during the admission (within $24 \mathrm{~h}$ ) $\mathrm{n}=102$ 
bath on groin colony count at $2 \mathrm{~h}$, and Table 5 shows that there is a significant difference noticed in groin colony count at $24 \mathrm{~h}$ in subjects received saline bath and standard care $(\mathrm{p}<0.05)$

Table 1 clearly shows that chlorhexidine bath saline bath and standard bath on bacterial colonization on the axilla at $2 \mathrm{~h}$ of intervention was not significant.

Table 3 shows that chlorhexidine bath, saline bath, and standard bath on axillary colony count at $24 \mathrm{~h}$ of intervention was not significant.

\section{DISCUSSION}

This study was done on children who got admitted and was not able to take bath independently and needed sponge bath. Demographic data revealed that $41(40.2 \%)$ were between the age group of $0-1$ years. $34(33.3 \%)$ were between 2 and 6 years and the mean age was 1.86 years. The higher number of infants among hospitalized children is the trend that is being observed in other studies as well [9]. Among the study participants, most of them were males $(61.8 \%)$, which is comparable with a similar study done at AIIMS [8]. Of 102 children who got admitted in the pediatric medical wards in this study, $71(69.6 \%)$ were from rural community, 40 (39.2\%) were from middle-income family, and 39 (38.23\%) of them were from a lower income family.

Pre-swab was taken from the children within $24 \mathrm{~h}$ of admission to the ward showed high colony counts in the axilla, groin which is similar to the other study finding where majority of the children had high axillary (71.56\%) and groin (67.64\%) colony count on admission (10)

Table 1: Frequency and percentage distribution of subjects based on demographic characteristics. $\mathrm{n}=102$

\begin{tabular}{|c|c|c|c|c|}
\hline Demographic variable & Chlorhexidine bath $\mathrm{n}(\%)$ & Saline bath n (\%) & Standard bath n (\%) & Total n (\%) \\
\hline \multicolumn{5}{|l|}{ Age } \\
\hline Infant & $13(38.2)$ & $16(47.1)$ & $12(35.3)$ & $41(40.2)$ \\
\hline Preschooler & $12(35.3)$ & $10(29.4)$ & $12(35.3)$ & $34(33.3)$ \\
\hline Schooler & $9(26.5)$ & $8(23.5)$ & $10(29.4)$ & $27(26.5)$ \\
\hline \multicolumn{5}{|l|}{ Sex } \\
\hline Male & $21(61.8)$ & $22(64.7)$ & $20(58.8)$ & $63(61.8)$ \\
\hline Female & $13(38.2)$ & $12(35.3)$ & $14(41.2)$ & $39(38.2)$ \\
\hline Rural & $22(64.7)$ & $25(73.5)$ & $24(70.6)$ & $71(69.6)$ \\
\hline Urban & $12(35.3)$ & $9(26.5)$ & $10(29.4)$ & $31(30.4)$ \\
\hline \multicolumn{5}{|l|}{ Socioeconomic status } \\
\hline Lower class & $11(32.4)$ & $17(50.0)$ & $11(32.4)$ & $39(38.3)$ \\
\hline Middle class & $15(44.1)$ & $13(38.2)$ & $12(35.3)$ & $40(39.2)$ \\
\hline Upper class & $8(23.5)$ & $4(11.8)$ & $11(32.4)$ & $23(22.5)$ \\
\hline
\end{tabular}

Table 2: Distribution of children according to the effectiveness of chlorhexidine bath saline bath and standard bath on bacterial colonization on the axilla at $2 \mathrm{~h}$ of intervention. $\mathrm{n}=102$

\begin{tabular}{|c|c|c|c|c|c|c|c|c|}
\hline \multicolumn{3}{|l|}{ Intervention given } & \multicolumn{4}{|c|}{ Axillary colony count at $\mathbf{2} \mathrm{h}$} & \multirow{2}{*}{$\begin{array}{l}\text { McNemar's Chi-square value } \\
5.2\end{array}$} & \multirow{2}{*}{$\begin{array}{l}\text { p value } \\
0.518\end{array}$} \\
\hline Chlorhexidine bath $(n=34)$ & Baseline & & No growth & Scanty & Moderate & High & & \\
\hline & 2 & No growth & 2 & 0 & 0 & 0 & & \\
\hline & 5 & Scanty & 1 & 2 & 0 & 2 & & \\
\hline & 5 & Moderate & 1 & 1 & 0 & 3 & & \\
\hline & 22 & High & 1 & 3 & 1 & 17 & & \\
\hline \multirow[t]{3}{*}{ Saline bath $(n=34)$} & 3 & No growth & 3 & 0 & 0 & 0 & 12.00 & 0.062 \\
\hline & 5 & Scanty & 3 & 0 & 1 & 1 & & \\
\hline & 24 & High & 1 & 3 & 5 & 15 & & \\
\hline \multirow{4}{*}{ Standard bath $(n=34)$} & 1 & No growth & 1 & 0 & 0 & 0 & 10.00 & 0.075 \\
\hline & 2 & Scanty & 0 & 2 & 0 & 0 & & \\
\hline & 4 & Moderate & 1 & 3 & 0 & 0 & & \\
\hline & 27 & High & 1 & 2 & 3 & 21 & & \\
\hline
\end{tabular}

Table 3: Distribution of children according to the effectiveness of chlorhexidine bath, saline bath, and standard bath on axillary colony count at $24 \mathrm{~h}$ of intervention. $n=102$

\begin{tabular}{|c|c|c|c|c|c|c|c|c|}
\hline \multicolumn{3}{|l|}{ Intervention given } & \multicolumn{4}{|c|}{ Axillary colony count at $24 \mathrm{~h}$} & \multirow{2}{*}{$\begin{array}{l}\text { McNemar's Chi-square value } \\
1.333\end{array}$} & \multirow{2}{*}{$\begin{array}{l}\text { p value } \\
0.513\end{array}$} \\
\hline Chlorhexidine bath $(n=34)$ & Baseline & & No growth & Scanty & Moderate & High & & \\
\hline & 2 & No growth & 2 & 0 & 0 & 0 & & \\
\hline & 5 & Scanty & 0 & 5 & 0 & 0 & & \\
\hline & 5 & Moderate & 0 & 0 & 4 & 1 & & \\
\hline & 22 & High & 0 & 1 & 2 & 19 & & \\
\hline \multirow[t]{3}{*}{ Saline bath $(n=34)$} & 3 & No growth & 2 & 1 & 0 & 0 & 1.867 & 0.760 \\
\hline & 5 & Scanty & 0 & 1 & 2 & 2 & & \\
\hline & 24 & High & 0 & 3 & 2 & 19 & & \\
\hline \multirow[t]{4}{*}{ Standard bath $(n=34)$} & 1 & No growth & 0 & 0 & 0 & 1 & 10.00 & 0.075 \\
\hline & 2 & Scanty & 0 & 0 & 1 & 1 & & \\
\hline & 4 & Moderate & 0 & 1 & 1 & 2 & & \\
\hline & 27 & High & 0 & 2 & 3 & 22 & & \\
\hline
\end{tabular}


Table 4: Effectiveness of chlohexidine bath, saline bath, and standard bath on groin bacterial colonization at $2 \mathrm{~h}$ of intervention. $\mathrm{n}=102$

\begin{tabular}{|c|c|c|c|c|c|c|c|c|}
\hline \multicolumn{3}{|c|}{ Intervention given } & \multicolumn{4}{|c|}{ Groin colony count at $2 \mathrm{~h}$} & \multirow{2}{*}{$\begin{array}{l}\text { McNemar's Chi-square value } \\
13.13\end{array}$} & \multirow{2}{*}{$\begin{array}{l}\text { p value } \\
0.041^{*}\end{array}$} \\
\hline Chlorhexidine & Baseline & & No growth & Scanty & Moderate & High & & \\
\hline \multirow[t]{3}{*}{ bath $(n=34)$} & 4 & No growth & 3 & 1 & 0 & 0 & & \\
\hline & 4 & Moderate & 1 & 1 & 2 & 0 & & \\
\hline & 21 & High & 4 & 2 & 5 & 10 & & \\
\hline Saline & 2 & No growth & 1 & 0 & 0 & 1 & 9.00 & 0.109 \\
\hline \multirow{2}{*}{ bath $(n=34)$} & 8 & Scanty & 3 & 3 & 2 & 0 & & \\
\hline & 22 & High & 3 & 2 & 5 & 12 & & \\
\hline \multirow{4}{*}{$\begin{array}{l}\text { Standard } \\
\text { bath }(n=34)\end{array}$} & 4 & No growth & 1 & 1 & 1 & 1 & 9.00 & 0.174 \\
\hline & 1 & Scanty & 0 & 1 & 0 & 0 & & \\
\hline & 3 & Moderate & 0 & 1 & 0 & 2 & & \\
\hline & 26 & High & 2 & 5 & 4 & 15 & & \\
\hline
\end{tabular}

*Significant $\mathrm{P}<0.05$

Table 5: Effectiveness of chlorhexidine bath, saline bath, and standard bath on groin bacterial colonization at $24 \mathrm{~h}$ of intervention. $\mathrm{n}=\mathbf{1 0 2}$

\begin{tabular}{|c|c|c|c|c|c|c|c|c|}
\hline \multicolumn{3}{|l|}{ Intervention given } & \multicolumn{4}{|c|}{ Groin colony count at $24 \mathrm{~h}$} & \multirow{2}{*}{$\begin{array}{l}\text { McNemar's } \\
\text { Chi-square value } \\
5.00\end{array}$} & \multirow{2}{*}{$\begin{array}{l}\text { p value } \\
0.544\end{array}$} \\
\hline Chlorhexidine bath $(n=34)$ & Baseline & & No growth & Scanty & Moderate & High & & \\
\hline & 4 & No growth & 2 & 2 & 0 & 0 & & \\
\hline & 5 & Scanty & 2 & 0 & 0 & 3 & & \\
\hline & 4 & Moderate & 1 & 1 & 1 & 1 & & \\
\hline & 21 & High & 2 & 6 & 1 & 12 & & \\
\hline \multirow[t]{3}{*}{ Saline bath $(n=34)$} & 2 & No growth & 2 & 0 & 0 & 0 & 14.66 & $0.023^{*}$ \\
\hline & 2 & Moderate & 1 & 0 & 1 & 0 & & \\
\hline & 22 & High & 2 & 4 & 8 & 8 & & \\
\hline \multirow[t]{4}{*}{ Standard bath $(n=34)$} & 4 & No growth & 1 & 3 & 0 & 0 & 13.77 & $0.032^{*}$ \\
\hline & 1 & Scanty & 0 & 0 & 1 & 0 & & \\
\hline & 3 & Moderate & 1 & 0 & 0 & 2 & & \\
\hline & 26 & High & 2 & 4 & 7 & 13 & & \\
\hline
\end{tabular}

*Significant $\mathrm{P}<0.05$

in the same instant $6 \%$ of children had no growth in the axilla and $10 \%$ of children had no growth in the groin. In addition to the axillary and groin colony count, umbilicus is another common area where bacterial colonization is assessed for generally [1], but in this study, this area was not included because of financial constraints related to the cost of laboratory tests. Moreover, coagulase-negative staphylococcus was the most common microorganism present in the axilla (88.2\%) and groin $(78 \%)$ of the children during the admission in this study which is comparable to the other study finding which showed high colony count with coagulase-negative staphylococci (42.1\%), SA (29.4\%), Escherichia coli (6.4\%), and Acinetobacter (6.0\%) [10].

Skin cleansing with chlorhexidine has been demonstrated in reducing the skin flora since 1960's whether it is used as a hand scrub or bathing solution [11]. Chlorhexidine gluconate + cetrimide has a broad antimicrobial activity against bacteria, fungi, and enveloped viruses and protozoa, and constant usage of these antiseptics for cleansing can reduce the spread of pathogenic microorganisms among the subjects [12], but the investigator was interested in exploring other solutions which had been tried and proven to be cost-effective and equally efficient like chlorhexidine in reducing the bacterial load on the skin with the hypothesis that saline and standard soap and water also will effectively reduce the bacterial colony count on the skin.

This hypothesis was refuted as the findings showed no difference in the bacterial colony count in the axilla at 2 and $24 \mathrm{~h}$ post-intervention in saline as well as chlorhexidine and the standard soap and water bath groups. However, the findings of the study provided vital information to the health-care professionals by showing the effectiveness of each solution at different intervals in reducing the colony count in the groin.
Chlorhexidine could bring down the bacterial load on the groin at $2 \mathrm{~h}$ significantly, but the same significant difference was not maintained at $24 \mathrm{~h}$. In the saline and standard bath group, although there was a reduction in the colony count at $2 \mathrm{~h}$, the difference was not statistically significant. The reduction, however, was significant at $24 \mathrm{~h}$ in both these groups. There are several studies which are supporting and contradicting the findings of this study $[9,12,14,15]$.

As discussed earlier and contrary to some of the study findings [8], none of these solutions were effective in bringing the bacterial colony count on the axilla in this study. The researcher assumes that this may have been because mothers usually carry children by holding them by the axilla, and the axilla can get contaminated by the organisms present in the hands of the mother. Most of the subjects in this study were in the age group of $0-1$ year, who were more likely to be carried than older children. Therefore, it is important to teach our mothers the appropriate way of holding children. The Childhood Development Institute suggests to carry the children by holding them at their back, supporting the buttocks and head. Holding the children by axilla may prevent any change in the bacterial colony count even if an intervention is provided.

\section{CONCLUSION}

It is important to note that there was no significant difference in the colonization in the axilla at $2 \mathrm{~h}$ and at $24 \mathrm{~h}$ with any of the two interventions and in the standard bath, but there was a significant difference in the groin colony count in the chlorhexidine group at $2 \mathrm{~h}$, and the difference was significant at $24 \mathrm{~h}$ in saline and standard bath. Since chlorhexidine has shown to be effective at $2 \mathrm{~h}$, it can be adopted for 
children who are undergoing invasive procedures and preoperatively in surgical wards while continuing routine standard bath for all children which is considered to be cost effective too.

\section{AUTHOR'S CONTRIBUTION}

The authors have contributed substantially to the study from the conception of the problem, data collection, data analysis, and drafting the manuscript.

\section{CONFLICTS OF INTEREST}

The authors declared that they have no conflicts of interest.

\section{ACKNOWLEDGMENT}

The authors would like to acknowledge the Institution Review Board of C.M.C, Vellore, for granting the financial support for the study.

\section{REFERENCES}

1. Otto M. Staphylococcus colonization of the skin and antimicrobial peptides. Expert Rev Dermatol 2010;5:183-95.

2. Mir BA, Srikantha. Prevalence and antimicrobial susceptibility of methicillin resistant Staphylococcus aureus and coagulase-negative staphylococci in a tertiary care hospital. Asian J Pharm Clin Res 2013;6:231-4.

3. Rahman H. Optimizing nasal formulation for prevention of serious infections caused by MRSA. Int J Pharm Pharam Sci 2015;7:496-503.

4. Ahoyo TA, Bankolé HS, Adéoti FM, Gbohoun AA, Assavèdo S, Amoussou-Guénou M, et al. Prevalence of nosocomial infections and anti-infective therapy in Benin: Results of the first nationwide survey in 2012. Antimicrob Resist Infect Control 2014;3:17.

5. Cogen AL, Nizet V, Gallo RL. Skin microbiota: A source of disease or defence? Br J Dermatol 2008;158:442-55.
6. Medves JM, O’Brien B. Does bathing newborns remove potentially harmful pathogens from the skin? Birth 2001;28:161-5.

7. Tielsch JM, Darmstadt GL, Mullany LC, Khatry SK, Katz J, LeClerq SC, et al. Impact of newborn skin-cleansing with chlorhexidine on neonatal mortality in southern Nepal: A community-based, cluster-randomized trial. Pediatrics 2007;119:e330-40.

8. Sankar MJ, Paul VK, Kapil A, Kalaivani M, Agarwal R, Darmstadt GL, et al. Does skin cleansing with chlorhexidine affect skin condition, temperature and colonization in hospitalized preterm low birth weight infants? A randomized clinical trial. J Perinatol 2009;29:795-801.

9. Gill PJ, Goldacre MJ, Mant D, Heneghan C, Thomson A, Seagroatt V, et al. Increase in emergency admissions to hospital for children aged under 15 in England, 1999-2010: National database analysis. Arch Dis Child 2013;98:328-34

10. Mullany LC, Khatry SK, Sherchand JB, LeClerq SC, Darmstadt GL, Katz J, et al. A randomized controlled trial of the impact of chlorhexidine skin cleansing on bacterial colonization of hospital-born infants in Nepal. Pediatr Infect Dis J 2008;27:505-11.

11. Evans HL, Dellit TH, Chan J, Nathens AB, Maier RV, Cuschieri J, et al. Effect of chlorhexidine whole-body bathing on hospital-acquired infections among trauma patients. Arch Surg 2010;145:240-6.

12. Olorode OA, Ogba AB. Antimicrobial activities of chlorhexidine gluconate and cetrimide against pathogenic microorganisms isolated from slaughter houses in rivers state, Nigeria. Int J Pharm Pharm Sci 2014;7:320-8

13. Chen W, Li S, Li L, Wu X, Zhang W. Effects of daily bathing with chlorhexidine and acquired infection of methicillin-resistant Staphylococcus aureus and vancomycin-resistant enterococcus: A meta-analysis. J Thorac Dis 2013;5:518-24.

14. Chlebicki MP, Safdar N, O’Horo JC, Maki DG. Preoperative chlorhexidine shower or bath for prevention of surgical site infection: A meta-analysis. Am J Infect Control 2013;41:167-73.

15. Climo MW, Yokoe DS, Warren DK, Perl TM, Bolon M, Herwaldt LA, et al. Effect of daily chlorhexidine bathing on hospital-acquired infection. N Engl J Med 2013;368:533-42. 